Studia i materiały $\mathrm{z}$ dziedzictwa kulturowego Torunia i regionu, t. 1: STARE I NOWE DZIEDZICTWO TORUNIA,

Toruń 2013

http://dx.doi.org/10.12775/SiMzDzKTiR_T1.2013.015

Matgorzata Wawrzak

(IZIK UMK, TORUŃ)

\title{
Treści polityczne zawarte w dekoracjach fundacji burmistrza Henryka Strobanda. Przyczynek do ikonosfery nowożytnego Torunia
}

\author{
„Religia, Muzy, Ubóstwo, Prawo, Ojczyzna, \\ Obywatele, Potomność i Pokój - nasze zamiłowanie"1
}

W sali mieszczańskiej toruńskiego ratusza, wśród wielu portretów znamienitych obywateli tego miasta, znajduje się portret zasłużonego dla rozwoju nowożytnego Torunia burmistrza Henryka Strobanda (1548-1609), który pełnił ten urząd w latach 1587-1609, a czas jego rządów nazywany jest „Złotym Wiekiem” w dziejach miasta ${ }^{2}$. Cytat zamieszczony jako motto pochodzi z inskrypcji umieszczonej na kominku w Sali Rady toruńskiego ratusza z 1603 roku i zawiera najważniejsze kwestie, które zajmowały burmistrza i znalazły odbicie w jego reformach społecznych i politycznych.

Badacze, a szczególnie historycy, od dawna zajmowali się działalnością tego wybitnego polityka ${ }^{3}$. U podłoża jego mądrych rządów leżało z pewnością wszechstronne wykształce-

1 Religio, Musae, pauper, lex, patria, amici / Civis, posteritas, pax quoque noster amor/. Tekst łaciński za: Marek FARBISZEWSKI, Opis Torunia z początku XVIII wieku. Tzw. Memoranda Jana Baumgartena, [w:] Miscellanea źródłowe do historii kultury i sztuki Torunia, red. B. DYBAŚ, M. FARBISZEWSKI, Wrocław 1989, („Źródła i materiały do dziejów sztuki polskiej” 22, red. M. ARSZYŃSKI), Wrocław 1989 [dalej cyt. MISCELLANEA 1989], s. 136; tłumaczenie za: Eugeniusz GĄSIOROWSKI, Ratusz Staromiejski w Toruniu, Toruń 2004, s. 101.

2 Piotr BIRECKI, Toruń burmistrza Henryka Strobanda, czyli miasto doskonałe, [w:] Henryk Stroband (1548-1609) - burmistrz toruński. W czterechsetna rocznicę śmierci, red. K. MIKULSKI, Toruń 2010 [dalej cyt. HENRYK STROBAND 2010], s. 62-91, zwł. s. 62.

3 Henryk RIETZ, Burmistrz Henryk Stroband (1548-1609), twórca Toruńskiego Gimnazjum Akademickiego, [w:] Księga Pamiątkowa 400-lecia Toruńskiego Gimnazjum Akademickiego [dalej cyt. KSIĘGA PAMIĄTKOWA 1972], t. 1, XVI-XVIII w., red. Z. ZDRÓJKOWSKI, Toruń 1972, s. 13-39 (tam też wcześniejsza literatura); Zbigniew ZDRÓJKOWSKI, Henryk Stroband (1548-1609), burmistrz i promotor Gimnazjum Akademickiego w Toruniu, [w:] Wybitni ludzie dawnego Torunia, red. M. BISKUP, Warszawa-Poznań 1982, s. 37-46; Henryk RIETZ, Henryk Stroband, [w:], Stownik biograficzny Pomorza Nadwiślańskiego, t. 4, red. Z. NOWAK, Gdańsk 1997, s. 283; Bogusław DYBAŚ, Burmistrz reformator. Wokól programu reformatorskiego Henryka Strobanda, „Zapiski Historyczne”, t. 66, 2001, z. 4, s. 29-43; TENŻE, Stroband Henryk, [w:] Toruński słownik biograficzny, red. K. MIKULSKI, t. 3, Toruń 2002, s. 211-217; Janusz MAŁŁEK, Burmistrz Henryk Stroband (1548-1609), reformator instytucji miejskich i wspóltwórca Gimnazjum Akade- 
nie, które uzyskał na wielu znanych europejskich uczelniach ${ }^{4}$, a szeroka wiedza zarówno z dziedziny filozofii, prawa cywilnego i kanonicznego, teologii, historii oraz polityki, jak i jego zdecydowanie irenistyczne poglądy pozwoliły określić go mianem „humanisty na miarę europejską"5. W czasie pełnienia obowiązków burmistrza, Stroband przeprowadził liczne reformy, wzmacniające zarówno prawo miejskie, jak i pozycję ekonomiczną protestanckiego wówczas Torunia ${ }^{6}$. Troszczył się o rozwój oświaty, wprowadzając w życie reformę Gimnazjum Akademickiego. Jego mądrze prowadzone rządy przyczyniły się do rozwoju miasta, w szczególności jego obronności i szkolnictwa a gospodarczemu prosperity Torunia towarzyszyła żywa działalność kulturalna i budowlana. To za jego rządów gruntownie przebudowano Ratusz Staromiejski i opracowano budowę miejskich fortyfikacji ${ }^{7}$. Henryk Stroband zaliczał się do toruńskiej elity intelektualnej, która się wokół niego skupiała. Do jego współpracowników należeli nie tylko członkowie Rady, ale też, a może w szczególności, grono wybitnych pedagogów Gimnazjum. ${ }^{8}$

Przedmiotem naszego zainteresowania są głównie tematy i treści zawarte w dekoracjach, które zdobiły strobandowskie fundacje i miały zdecydowane odniesienie do licznych przeprowadzonych przez niego reform, lecz przede wszystkim były odzwierciedleniem zarówno przekonań religijnych burmistrza i toruńskiej elity, jak też niezaprzeczalnych wpływów środowiska gdańskiego ${ }^{9}$. W obydwu współpracujących i jednocześnie rywalizujących ze sobą miastach pojawiają się takie same lub zbliżone stylowo, formalnie i tematycznie realizacje. Możemy tutaj jedynie zasygnalizować, jak zostały odczytane w literaturze oraz wskazać obszary, które wymagają dalszych wnikliwych badań.

Strobandowi przypisuje się powstanie większości obiektów z tego czasu, zarówno budowli municypalnych jak i dzieł wchodzących w skład wyposażenia przejętych przez protestantów toruńskich świątyń. Niestety, większość tych fundacji nie zachowała się, znamy je jedynie z rysunków Steinera pochodzących z pierwszej poł. XVIII w. ${ }^{10}$ Są to: budynek arsenału miejskiego (il. 1), budynek głównego odwachu (il. 2), czy bursa Toruńskiego Gimnazjum Akademickiego zwana „Ekonomią” (il. 3).

mickiego w Toruniu, [w:] HENRYK STROBAND 2010, s. 44-61.

4 Studiował we Frankfurcie nad Odrą, Tybindze, Wittenberdze, Strasburgu, Bazylei. TAMŻE, RIETZ 1972, s. 13-16.

5 GĄSIOROWSKI 2004, s. 91.

6 W 1558 roku Toruń uzyskał przywilej wolności wyznaniowej króla Zygmunta Augusta. Wystawienie tego dokumentu wyznaczało przełom w dziejach toruńskiego protestantyzmu: Michał TARGOWSKI, Ruch protestancki do końca 1558 roku, [w:] Ewangelicy w Toruniu (XVI-XX w.), zbiór studiów pod red. J. KŁACZKOW, Toruń 2011 [dalej cyt. EWANGELICY W TORUNIU 2011], s. 13-38.

7 Bogusław DYBAŚ, Dzieje wojskowe Torunia w latach 1548-1660, [w:] Historia Torunia, red. M. BISKUP, t. 2, cz. 2, Toruń 1994, s. 141-168, zwł. s. 144-145.

8 DYBAŚ 2002, s. 212.

9 Jadwiga PUCIATA-PAWŁOWSKA, Z dziejów stosunków artystycznych Torunia $i$ Gdańska w XVI $i$ XVII w., „Teka Komisji Historii Sztuki TNT", t. 1, 1959, s. 143-238, zwł. 211-220.

10 Toruń i miasta ziemi chełmińskiej na rysunkach Jerzego Fryderyka Steinera z pierwszej połowy XVIII wieku (tzw. Album Steinera), red. M. BISKUP, Toruń 1998 (dalej cyt. ALBUM STEINERA). 
Za najważniejszą inwestycję miejską przeprowadzoną z inicjatywy burmistrza uznaje się przebudowę ratusza, w tym miejscu jednak wypada zacząć od reformy Gimnazjum Toruńskiego, która od początku sprawowania urzędu była dla Strobanda szczególnie ważna. Rozbudowując szkołę toruńską, burmistrz miał aspiracje daleko wykraczające poza lokalne potrzeby miasta. Jednym z jego ambitnych planów było podniesienie tej szkoły do rangi Akademii protestanckiej dla całej Rzeczypospolitej ${ }^{11}$. Wielki wpływ na te zmiany miały same podróże i studia zagraniczne Henryka, który przebywając na zachodzie miał okazję obserwować funkcjonowanie tamtejszych uczelni. Wzorował się szczególnie na przykładzie uczelni strasburskiej - Jana Sturma, pod każdym względem naśladując jego program oraz wybór podręczników, których używano do nauki łaciny, greki i kultury antycznej. W szkole nowego, humanistycznego typu kładziono bowiem nacisk właśnie na naukę łaciny i greki, a nade wszystko - retoryki i historii starożytnej ${ }^{12}$. Aby zapewnić odpowiedni poziom w wykształceniu młodzieńca biegłego w pisaniu i czytaniu oraz w wygłaszaniu mów w cycerońskiej konwencji - co było głównym założeniem programu nauczania, niezbędne było założenie bogatej biblioteki. Stało się to, gdy rada miejska Torunia w 1594 roku podjęła uchwałę o przekazaniu księgozbioru radzieckiego i dawnej biblioteki franciszkanów jako zaczątku książnicy gimnazjum. Sam burmistrz przekazał tu swój bogaty księgozbiór ${ }^{13}$.

Biblioteka zajęła pomieszczenia na najwyższym piętrze dawnego klasztoru franciszkańskiego ${ }^{14}$. Autorem pierwszego opisu, Descriptio Bibliothecae Scholae Thorunensis, był jej ówczesny prorektor Ulrych Schober (1559-1598) ${ }^{15}$. Dla nas szczególnie istotny jest rozdział V, gdzie autor obok poszczególnych działów wymienia też szereg malowideł i portretów ${ }^{16}$. Cały zasób biblioteki podzielony został na dwadzieścia pięć działów tematycznych. Dużą część stanowiły dzieła historyczne i prawnicze, teologiczne oraz filozofów antycznych. Każdy z działów był ozdobiony dopasowanymi do jego zawartości malowanymi przedsta-

11 Zamiar utworzenia protestanckiej Akademii pojawił się na krótko po przeprowadzeniu przez Henryka reformy Gimnazjum Toruńskiego założonego przez jego ojca, Jana Strobanda. Było to w latach 1594-1595, kiedy to Henryk Stroband wraz z profesorami związanymi z Gimnazjum powziął takie starania wzorem uczelni strasburskiej. Stanisław TYNC, Ślązak Ulryk Schober konrektor i działacz kulturalny toruński (1559-1598), Kraków-Wrocław 1960, s. 199; Stanisław Salmonowicz, Kultura umysłowa Torunia $w$ dobie renesansu, reformacji $i$ wczesnego baroku, [w:] Historia Torunia, red. M. BISKUP, t. 2, cz. 2, Toruń 1994, s. 169-256, zwł. s. 254.

12 Leon WITKOWSKI, Nauka łaciny i greki w toruńskim Gimnazjum Akademickim w XVI-XVIII w., [w:] KSIĘGA PAMIĄTKOWA 1972, s. 71-112, zwł. s. 91; SALMONOWICZ 1994, s. 254.

13 RIETZ 1972, s. 31; Książnica Miejska im. Mikołaja Kopernika powstała w 1923 r. - włączony do niej został cały księgozbiór biblioteki gimnazjalnej oraz Towarzystwa Naukowego i Coppernicus-Verein, Krystyna PODLASZEWSKA, Notitia Bibliothecae Thorunensis Piotra Jaenichiusa z 1723 r. Przyczynek do dziejów biblioteki gimnazjum toruńskiego, seria: „Zeszyty naukowe UMK w Toruniu”, Nauki Humanistyczno-Społeczne, z. 13, Nauki o książce, t. 3, 1965, s. 3-41, zwł. s. 9.

14 Zwolennicy reformacji w 1557 r. przejęli ostatecznie we władanie kościół franciszkański NMP, a dwa lata później w ich ręce przeszły również zabudowania poklasztorne. Piotr BIRECKI, Protestancki okres kościoła Najświętszej Panny Marii w Toruniu (1557-1724), [w:] Sztuka i dialog wyznań w XVI i XVII w., Warszawa 2000, s. 295-305, zwł. s. 300.

15 Opis biblioteki sporządzony przez prorektora Gimnazjum Ulryka Schobera opublikował Stanisław Tync w biografii tego humanisty i poety: Tync 1960, s. 241-258. Jednak pierwszy drukowany, dokładny opis biblioteki toruńskiej pochodzi z XVIII w. a podaje go Piotr Jaenichius, ówczesny rektor gimnazjum, [za:] PODLASZEWSKA 1965, s. 4 .

16 TYNC 1960, s. 251-252. 
wieniami alegorycznymi, postaciami mitologicznymi, antycznych myślicieli oraz portretami współczesnych reprezentantów danej dziedziny nauki ${ }^{17}$. Możemy wymienić jedynie niektóre $\mathrm{z}$ nich.

Klasę pierwszą, która dotyczyła organizacji bibliotek i szkolnictwa zdobiła Tabula Cebetis oraz dwa portrety: Konrada Gesnera - znanego szwajcarskiego twórcy nowożytnej bibliografii i Jana Sturma - humanisty i pedagoga, założyciela słynnego Gimnazjum w Strasburgu, które (jak wyżej wspomniano) było wzorem dla Gimnazjum Toruńskiego. Kolejne działy zdobiły m. in.: personifikacje Gramatyki (Grammatica) i Poezji (Poesis), Dialektyki (Dialectica) i Retoryki (Rhetorica), Filozofii czyli Mądrości (Philosophia sive sapientia), Muzyki (Musica), Przyrody (Natura rerum), Zdrowia (Sanitas), Powściągliwości (Temperantia), Mądrości (Prudentia), Czasu (Imago temporis), Jasności narracji (Candor seu Parrhesia), Prawdy (Veritas), personifikacje Czterech Kontynentów (Europa, Aphrica, Asia, America), Sprawiedliwości (Iustitia), Męstwa (Fortitudo). Odpowiednie tematy działów zdobiły też portrety pisarzy, poetów czy filozofów klasycznych, jak: Liwiusz, Tukidydes, Homer, Wergiliusz, Platon czy Arystoteles; nie mogło wśród nich zabraknąć wyobrażenia Cycerona, który dla ludzi renesansu był nauczycielem retoryki i stylu, a nade wszystko dawał praktyczną wykładnię myśli obywatelskiej ${ }^{18}$. Astronomii patronował Mikołaj Kopernik, architekturze zaś - Witruwiusz i Michał Anioł.

Wśród wybitnych współczesnych reprezentantów poszczególnych działów znalazły się m. in. portrety: Orlanda di Lasso - wybitnego włoskiego kompozytora, przedstawiciela polifonii renesansowej, czynnego w Antwerpii; Abrahama Buchholtzera - historyka, ucznia Filipa Melanchtona; Andreasa Hyperiusa - teologa, profesora teologii w Marburgu; Philipa Comines'a - Flamanda, historyka i dyplomaty na dworze burgundzkim. Wymownymi symbolami opatrzono działy teologii: katolicka została ozdobiona przedstawieniem zaćmienia słońca i personifikacją przesądu (Superstitio) oraz portretami św. Franciszka i św. Dominika, natomiast klasy teologii protestanckiej otrzymały personifikację Nadziei, wyobrażenie wschodzącego słońca oraz portrety reformatorów - Marcina Lutra i Filipa Melanchtona.

Nowe programy nauczania w protestanckich gimnazjach akademickich, zarówno w Toruniu, jak Gdańsku i Elblągu, uczyniły z nich główne ośrodki studiów klasycznych na terenie Prus Królewskich. Łączyły teologię protestancką i tradycyjne dyscypliny humanistyczne - filozofię, gramatykę i retorykę z nowymi przedmiotami, jak prawo, teoria polityczna i historia ${ }^{19}$. W Gimnazjum nade wszystko studiowano autorów antycznych, by zdobyć nobilitującą elokwencję oraz przydatne w oracjach i negocjacjach umiejętności retoryczne. Humanistów tego czasu łączył sposób poszukiwania wzorów etycznych w grecko-rzymskiej

17 Elementy wchodzące w skład dekoracji poszczególnych działów biblioteki omawia w swojej pracy doktorskiej Katarzyna KOLENDO-KORCZAK, Praecepta politica $w$ toruńskim ratuszu. Niezachowany cykl malowideł Antona Möllera z 1603 r. i jego europejski kontekst, Warszawa 2009, Autorce składam podziękowanie za udostępnienie maszynopisu (korzystałam z egzemplarza znajdującego się w Zbiorach Specjalnych Instytutu Sztuki PAN w Warszawie).

18 Marcin KALECIŃSKI, Mity Gdańska. Antyk w publicznej sztuce protestanckiej Res Publiki, („Gedania Artistica”, t. 1), Gdańsk 2011, s. 39.

19 Karin FRIEDRICH, Inne Prusy. Prusy Królewskie i polska miedzy wolnością a wolnościami (1569-1772),Poznań 2005, s. 109-110. 
schedzie filozoficznej. Istotnym kontekstem filozoficznym luteranizmu stała się w dobie nowożytnej filozofia stoicka, podstawowy komponent ówczesnego pojmowania humanitas, znany dzięki tłumaczeniom pism zwłaszcza Seneki i Cycerona ${ }^{20}$. Jak zauważył Janusz Małłek, w programie nauczania toruńskiego gimnazjum zabrakło nauk przyrodniczych i matematyki ${ }^{21}$.

Przebudowa ratusza (w latach 1602-1605) w duchu manieryzmu niderlandzkiego, której głównym pomysłodawcą był burmistrz Stroband, nie ograniczyła się jedynie do zmiany zewnętrznej bryły architektonicznej tego gmachu. Ratusz został podwyższony o jedno piętro, naroża otrzymały manierystyczne wieżyczki, a ściany zostały zwieńczone ozdobnymi szczytami ${ }^{22}$ (il. 4). Pomysłodawca zadbał szczególnie o bogaty wystrój sal ratuszowych, pełnych w treści sławiące dobre rządy a stanowiące wręcz swego rodzaju propagandę polityki i przeprowadzonych przez niego reform. Znalazły się tam wskazówki dla Rady oraz podkreślenie znaczenia Torunia na arenie międzynarodowej. Zarówno forma architektoniczna, jak i dekoracje wnętrz ratusza, niosły zwarty przekaz ikonograficzny o charakterze społecznym i politycznym ${ }^{23}$. Siedemnastowieczny toruński historyk Christoph Hartknoch tak opisał dzieło burmistrza:

Wyposażył Stroband ratusz tak wspaniałymi wnętrzami, że nawet z najwytworniejszymi w Europie a nawet całego świata mógł współzawodniczyć2 ${ }^{24}$.

Główne tezy i założenia rządów tego wyśmienitego polityka umieszczono w inskrypcjach na kominkach i portalach sal pierwszego piętra ratusza, a szczególnie w dekoracji malarskiej Sali Rady. Jedna z inskrypcji na prowadzącym do niej portalu odnosiła się do motta, którym Stroband zapoczątkował swój memoriał będący projektem ufortyfikowania Torunia, a który brzmiał:

Felix civitas quae pacis tempore timet bella (Szczęśliwe miasto, które w czasach pokoju obawia się wojny $)^{25}$.

Tarcze herbowe oraz tablica inskrypcyjna zostały wmontowane (po pożarze) w późno-

20 KALECIŃSKI 2011, s. 28.

21 MAŁŁEK, 2010, s. 44-61.

22 W tym celu burmistrz sprowadził do Torunia jednego z najbardziej znanych wówczas architektów, z którym wcześniej przygotowywał projekt nowożytnych fortyfikacji, Antoniego van Obberghena, Sławomir SZCZERBIŃSKI, Antoni van Obberghen (1543-1611) budowniczy i architekt, [w:] Artyści w dawnym Toruniu, red. J. POKLEWSKI, Warszawa-Poznań 1985, s. 44-52, s. 31; Bogusław DYBAŚ, Memoriał burmistrza Henryka Strobanda: „von Befestigung der Stadt Thorn” [w:] MISCELLANEA 1989, s. 21-95, zwł. s. 35, 92. Obberghen mógł uczestniczyć przy projekcie rozbudowy ratusza i chociaż te informacje nie są potwierdzone źródłowo, autor monografii tegoż obiektu uznaje, że bliskie kontakty Strobanda z tym architektem wskazują na niego jako projektanta i kierownika przebudowy toruńskiego Ratusza. Prace budowlano-kamieniarskie zlecono Wilhelmowi Mertenowi, który wykonał głównie prace kamieniarskie: obramienia okienne, wieżyczki i szczyty: GĄSIOROWSKI 2004, s. 92-93 i 116-117.

23 Piotr BIRECKI, Architektura i sztuka luterańska w Toruniu w okresie nowożytnym, [w:] EWANGELICY W TORUNIU 2011, s. 171-199, zwł. s. 191.

24 Christoph HARTKNOCH, Alt- und Neues Preussen oder Preussische Historien, Frankfurt-Leipzig 1684, s. 369, za GĄSIOROWSKI 2004, s. 100.

25 Krystyna KALINOWSKA, Malowane stropy w kamienicach Torunia XVI-XVIII w. („Studia z Historii Sztuki”, t. 48), Warszawa 1995, s. 21. 
barokowy portal z 1735 roku. Przy południowej ścianie Sali Rady znajdował się ponadto kominek ozdobiony tarczami z herbem Torunia oraz łacińską inskrypcją:

Ciepło natury jest umiarkowane, przyjaciółka rozkosz, Łagodna władza obyczajem, Pomyślność $w$ dostatkach, Rozważna rada - lek w teraźniejszych nieszczęściach. Jak umiarkowanie przynosi pożytek, tak popędliwość szkodzi. Rok $1603^{26}$.

Wielką salę widowiskową zdobił marmurowy kominek, na którym znalazła się inskrypcja:

Tam gdzie nieodmienna i trwała jest zgoda wśród obywateli, Bezpieczeństwo Rzeczypospolitej jest zapewnione ${ }^{27}$.

Kolejny fragment jest poświęcony tematowi zgody wśród obywateli oraz dobrym skutkom pokoju, a zgubnym wojny. W Sali Wielkiej zaś pojawił się cytat z księgi Salomona:

Troszczcie się o sprawiedliwość, ci którzy sądzicie na ziemi. Sąd bowiem Panu nie ludziom pokazujecie

$(\operatorname{Mdr} 1,1)^{28}$ oraz inskrypcja, dotycząca wprowadzania przez władze miejskie regulacji ograniczeń zbytku oraz pomocy najuboższym:

Cenzura, stróż Rzeczypospolitej, dzięki pomocy i staraniu której triumfuje pomyślność obywateli, wzrasta, jaśnieje, rozwija się siła i moc ojczyzny. Niech doznaje pomocy sprawa ubogich, niech maja staranie około sierot $i$ wdów ${ }^{29}$.

To jedynie fragmenty licznych inskrypcji, jakie pojawiły się na portalach i kominkach sal toruńskiego ratusza, które mają odpowiedniki w dekoracji malarskiej stropu Sali Rady. Malowidła na stropie, wykonane w latach 1602-1603 przez gdańskiego malarza Antoniego Möllera $^{30}$, były z pewnością niezwykle ciekawe pod względem zarówno formalnym jak i treściowym. Zniszczenie tego cennego dzieła przez wojska szwedzkie w 1703 roku jest więc stratą niepowetowaną, nie tylko dla wystroju toruńskiego ratusza, ale również dla ikonosfery tego protestanckiego miasta. Jedno ze źródeł inspiracji dla tej dekoracji stanowiły zapewne obrazy Vredemana de Vriesa, zdobiące Salę Czerwoną Ratusza Głównomiejskiego w Gdańsku. Należy jednak podkreślić, że - jak wykazała już wcześniej Jadwiga Puciata-Pawłowska - poziom artystyczny obrazów, zdobiących strop toruńskiej Sali Rady oraz ich oprawa snycerska były na tyle wysokie a zdobienia okazałe, że zrobiły ogromne wrażenie

26 GĄSIOROWSKI 2004, (tłum.), s. 101; tekst łaciński brzmi: Naturae calor est moderatus amica voluptas imperium placidum vita salusque bonis consilium sanum, praesens madicina malorum Sic moderata iuvant sic violentia nocent. Anno 1603, cyt. za FARBISZEWSKI, 1989, s. 136.

27 GĄSIOROWSKI 2004, (tłum.), s. 105; tekst łaciński brzmi: Ubi fortis et constans civium concordia, ibi firma est Reipublicae salus, cyt. za FARBISZEWSKI 1989, s. 147.

28 KOLENDO-KORCZAK 2009, (mps, patrz przyp. 17); tekst łaciński brzmi: Diligite iustitiam, qui iudicatis terram, iudicium enim Domini non hominum exserietis, cyt za: FARBISZEWSKI 1989, s. 148.

29 GĄSIOROWSKI 2004, (tłum.), s. 108; tekst łaciński brzmi: Censura custos reipublicae, cuius cura et praesidio, salus triumphat civium flos atque rober patriae crescit, renitet, geminat./ Causa iuvatur pauperum, rectissima consulitur pupillisatque viduis. cyt za: FARBISZEWSKI 1989, s. 148.

30 Anna MOSINGIEWICZ, Antoni Möller (ok. 1563-1611), malarz, [w:] Artyści w dawnym Toruniu, red. J. POKLEWSKI, Warszawa-Poznań 1985, s. 44-52, zwł. s. 47. 
na radzie gdańskiej, która postanowiła niedawno przecież wykonaną dekorację de Vriesa zastąpić nową ${ }^{31}$. Być może była to jedna z przyczyn, jednak jak twierdzi Eugeniusz Iwanoyko, bardziej prawdopodobne jest to, że dekoracja stropu Czerwonej Sali w Gdańsku wykonana przez Vredemana ograniczała się jedynie do ornamentów i groteski dekorujących przestrzenie między belkowaniem, tak charakterystycznych w manieryźmie dla stropów. Dlatego członkowie gdańskiej rady, postanowili zachować siedem obrazów sztalugowych zdobiących ściany wykonanych przez de Vriesa, natomiast dekorację stropu zastąpić nową, bardziej okazałą i odpowiadającą wymogom bogacącego się gdańskiego patrycjatu, co pozwoliło również na demonstrację określonych aspektów ideowych ${ }^{32}$.

Trudno dzisiaj dokonać analizy formalnej dekoracji malarskiej stropu Sali Rady toruńskiego ratusza, gdyż znane jest ono jedynie dzięki zachowanym w rękopisach wskazówkom dla malarza, dokładnie rozpisanym przez samego burmistrza Strobanda ${ }^{33}$. Na podstawie tejże instrukcji, dokładną analizę treści zawartych w wyobrażeniach przedstawionych na stropie przeprowadziła ostatnio Katarzyna Kolendo-Korczak ${ }^{34}$. Dekoracja składała się $\mathrm{z}$ dwunastu głównych przedstawień które były podzielone na pictura hierogliphica symbolica oder emblematica oraz pictura historia. Przedstawione na nich sceny stanowiły zapewne swoiste praecepta politica (zasady polityczne) dla sprawujących władzę, ukazując cnoty dobrego rajcy i rządzącej elity, dzięki którym możliwy był szczęśliwy byt i pomyślność miasta ${ }^{35}$. Personifikacje cnót w obrazach odnosiły się do treści religijnych (Opatrzność, Pobożność i Religia), pożądanych cech obywateli i rajców (Mądrość, Roztropność, Rada), zasad i celów działania władzy (Sprawiedliwość i Równość, Ochrona, Opieka nad sierotami, Stałość, Władza, Wzajemna harmonia, Pokój). Były uzupełnieniem dla obrazów, nasyconych treściami alegorycznymi, a szczególne miejsce przypadło motywom aktualizującym, które dotyczyły przemian społecznych, religijnych i oświatowych, zachodzących w tym czasie w Toruniu, np. obok personifikacji Rady umieszczono budynek ratusza, gdzie odbywały się posiedzenia rady miejskiej, natomiast obok personifikacji Czujności - budynek straży miejskiej, która czuwa nad bezpieczeństwem obywateli. Uzupełnieniem aktualnych wydarzeń były też sceny biblijne, jak: Mojżesz na górze Synaj, Budowa wieży Babel, Walka Dawida z Goliatem, Sąd Salomona, Sąd Dawida i Sąd nad Zuzanna z alegorią Mądrości, Roztropności i Rozwagi, które patronowały obradom rady miejskiej Torunia, ale też sesji senatu Republiki Weneckiej. Był to przykład bezpośredniego porównania rady Torunia z senatem Wenecji, która

31 PUCIATA-PAWŁOWSKA 1959, s. 143-238, zwł. s. 151.

32 Eugeniusz IWANOYKO, Sala Czerwona ratusza gdańskiego, Wrocław - Warszawa - Kraków - Gdańsk Łódź 1986, s. 76-77.

33 Instrukcja została przedrukowana [w:] Stanisław DĄBROWSKI, Malowidła Antoniego Möllera w Ratuszu Toruńskim, „Zapiski TNT”, t. 7, 1926-1928; opis kronikarski stropu w języku łacińskim został zamieszczony w aneksie: PUCIATA-PAWŁOWSKA 1959, s. 227-238.

34 KOLENDO-KORCZAK 2009 (maszynopis pracy doktorskiej, patrz przyp. 17); TENŻE, Propaganda reform burmistrza Henryka Strobanda $w$ dekoracji Sali Rady z 1603 roku w ratuszu staromiejskim $w$ Toruniu, „Zapiski Historyczne", t. 74, z. 3, 2009, s. 37- 60; wcześniejszej próby wskazania źródeł ikonograficznych dokonała Jadwiga PUCIATA-PAWŁOWSKA, Program ikonograficzny zaginionego stropu Antoniego Möllera w ratuszu toruńskim. „Zapiski Historyczne, t. 24, 1958-1959, s. 67-86.

35 TAMŻE oraz BIRECKI 2010, s. 85. 
w dobie nowożytnej stanowiła uosobienie republikańskich wartości, a mit, ukazujący jej konstytucję, stał się współczesną wersją antycznej mądrości politycznej36.

Personifikacja Sprawiedliwości uzupełniała wyobrażenie Opieki nad biednymi i sierotami, co stanowiło zapewne odniesienie do ordynacji burmistrza Strobanda Patrocinium Pupillorum, która regulowała sytuację prawną i majątkową osieroconych dzieci oraz zapewniała im wykształcenie, tak aby po osiągnięciu pełnoletniości mogły służyć społeczności jako jej obywatele. Personifikacja Opatrzności czuwała nad Rzeczpospolitą, która zasiadła na czterech kolumnach, przedstawionych jako Roztropność, Sprawiedliwość, Męstwo i Umiarkowanie. Do aktualnych tematów nawiązuje tablica z personifikacją Umiarkowania, która odnosi się do Nadzoru nad obyczajami i wydatkami ${ }^{37}$. Przepisy przeciw zbytkowi ogłaszane były w wilkierzach miejskich: regulowały noszenie zbyt kosztownych strojów, ozdób i biżuterii oraz wskazywały odpowiednie sposoby urządzania uczt czy uroczystości rodzinnych. Dla zobrazowania pouczeń moralnych i dobrych rad w części Pictura historica służyły exempla, np. z życia prawodawcy Likurga, Marka Katona, Herodota Sizamnesa, Horacjusza Koklesa, Arystydesa z Aten.

Strop został podzielony na dwanaście tablic i, jak twierdzą badacze ${ }^{38}$, nawiązywał do rzymskiego Prawa Dwunastu Tablic, co należy jednak poddać dyskusji. Źródeł, którymi mógł się posłużyć fundator-pomysłodawca, możemy upatrywać raczej w dziełach filozoficznych i literackich, szczególnie u przytaczanego już Cycerona, a zwłaszcza w jego dziele O powinnościach. Pełniło ono rolę podręcznika dla renesansowych patrycjuszy, dotyczyło etyki obywatelskiej oraz dawało pouczające przykłady z życia politycznego, obfitowało w dicta, praecepta i exempla. Jedno z jego wydań było bogato ilustrowane i stało się skarbnicą inspiracji dla konceptorów programów ikonograficznych dekoracji w ratuszach w Ulm, Norymberdze i Bazylei ${ }^{39}$. Również dzieło Lipsjusza, Politica, które weszło do kanonu lektur w Gimnazjum Toruńskim, było swoistym kompendium wiedzy dla rządzących, przez liczne odwołania do sentencji autorów starożytnych, m. in. Cycerona ${ }^{40}$. Wielu exemplów, ukazujących wydarzenia z życia bohaterów antycznych, mogły z kolei dostarczać popularne wówczas Gesta Romanorum, które były zbiorem przypowieści biblijnych, rycerskich, rzymskich. Kanon cnót niezbędnych dobremu władcy prezentowały też dzieła Erazma z Rotterdamu; wzorów tego typu nie brakowało również w popularnych podręcznikach emblematycznych, by wymienić tylko Alciatiego czy Paradina. Stroband mógł sięgnąć ponadto do licznych przykładów sztuki gdańskiej, np. wystroju Dworu Artusa, Ratusza Głównomiejskiego (zwłaszcza Sali Czerwonej) lub bram zdobionych antycznymi motywami. Nie brakowało ich też w wydawanych dziełach graficznych, drukach ulotnych, ilustracjach czy projektach, dla przykładu: projekty wyobrażeń personifikacji cnót, przeznaczonych do zwieńczenia Bramy

36 KALECIŃSKI 2011, s. 167.

37 KOLENDO-KORCZAK 2009, s. 52.

38 Jakub POKORA, „Nicolaus mein Herr, ich hab' kein' Rock mehr” (Die Gestalt des Narren Klaus im Ratsaal des Rathauses zu Thorn), „Biuletyn Historii Sztuki”, t. 49, nr 3-4, 1987, s. 271-272; KOLENDO-KORCZAK 2009, s. $39-40$.

39 KALECIŃSKI 2011, s. 39.

40 TAMŻE, s. 148. 
Długoulicznej w Gdańsku (il. 5).

Artystyczne upodobania Strobanda znalazły też swój wyraz w dekoracji wyposażenia kościoła Najświętszej Marii Panny, głównej świątyni toruńskich protestantów. Niezwykle ciekawy program ideowy otrzymały fundowane przez burmistrza organy (il. 6) i ambona (il. 7). Przedni prospekt organowy, zgodnie z boecjańską teorią muzyki podzielony na trzy domeny: muzyki zmysłów, muzyki instrumentalnej i muzyki sfer, zdobi bogata dekoracja snycerska. Na szczególną uwagę zwraca szeroki pas partii cokołowej, gdzie umieszczono wyobrażenia z panteonu bóstw mitologicznych, otaczających herby Torunia i Prus Królewskich (il.8). W najbliższym sąsiedztwie herbu Torunia znalazły się figury: Wenus i Mars, obok herbu Prus Królewskich: Neptun i Jowisz, na skrajach po prawej Hermes i Demeter, po lewej zaś Saturn i rzymski pretorianin ${ }^{41}$. Po raz kolejny wyobrażenia bóstw mitologicznych posłużyły burmistrzowi, autorowi programu, do przypisania ich cnót, takich jak: męstwo, odwaga, umiarkowanie, zgoda, dyplomacja, pracowitość, dbałość o bezpieczeństwo, wkład w rozwój handlu oraz żywa wiara i ufność w opiekę Opatrzności, obywatelom swojego miasta, tym którzy przyczynili się do osiągnięcia dobrobytu i pomyślności Torunia, a co za tym idzie, do podniesienia jego rangi na terenie Prus Królewskich i Rzeczypospolitej. Szczególny hołd złożył burmistrz królowi Zygmuntowi III Wazie, umieszczając jego portret pośrodku szeregu głów toruńskich mieszczan u dołu prospektu, w podziękowaniu za względy jakimi ten monarcha darzył miasto - jego częste wizyty przynosiły miastu niewątpliwy splendor ${ }^{42}$ (il. 9). Natomiast podział ambony na strefę ewangelii i strefę niebiańską wynikał z ideologii protestanckiej, ukazywał zbawienną rolę kazania i Triumf Kościoła ${ }^{43}$.

Nie wiemy, czy Stroband był fundatorem organów z kościoła św. Jakuba (il. 10), wzniesionych w rok po jego śmierci (1610-11), jednak umieszczenie na balustradzie herbów Rzeczypospolitej (z monogramem Zygmunta III Wazy), Prus Królewskich oraz Starego i Nowego Miasta Torunia, stanowi przykład wyjątkowej równowagi pomiędzy wolnością pruskiego Torunia a centralną władzą królewską ${ }^{44}$.

W podsumowaniu należy stwierdzić, że licznie zobrazowane exempla z historii i literatury starożytnej, personifikacje cnót czy wyobrażenia bóstw mitologicznych, stały się istotnym źródłem dla stworzenia alegorii dobrych rządów, środkiem perswazji i propagandy politycznej, komunikatem legitymizującym władzę, aktualną sytuację polityczną, religijną i społeczną miasta. Jak pisze Susan Tipton: „Reformacja pojmowana była nie tylko jako reforma

41 Małgorzata WAWRZAK, Humanistyczne i polityczne treści dekoracji organów z kościoła Mariackiego w Toruniu. Wprowadzenie do problematyki, [w:] Sztuka w kręgu władzy. Materiały z Sesji Naukowej Stowarzyszenia Historyków Sztuki, poświęconej pamięci Profesora Szczęsnego Dettloffa (1878-1961) w 130 rocznicę urodzin, Toruń 13-15 listopada 2008, red. E. PILECKA i K. KLUCZWAJD, Warszawa 2009, s. 205-217, zwł. s. 208-213.

42 TAMŻE, s. 213.

43 Małgorzata WAWRZAK, Ambona z kościoła Mariackiego na tle kultury artystycznej Torunia początku XVII wieku, [w:] Dzieje i skarby kościoła Mariackiego w Toruniu, Materiały z konferencji - Toruń, 14-16 kwietnia 2005 roku, red. K. KLUCZWAJD, Toruń 2005, s. 295-320.

44 Małgorzata WAWRZAK, O manierystycznej dekoracji prospektu organowego z kościoła pw. św. Jakuba w Toruniu. Wzory graficzne i treści, [w:] Dzieje i skarby kościoła Świętojakubskiego w Toruniu, Materiały z IV Sesji Naukowej O.T. Stowarzyszenia Historyków Sztuki, Dzieje i skarby kościołów toruńskich, red. K. KLUCZWAJD, Toruń 2010, s. 259-288. 
kultu religijnego, ale również wprowadzenie nowej definicji roli i statusu władzy świeckiej”" ${ }^{3}$. Stąd liczne pisma z zakresu teorii i etyki władzy odnosiły się i były oparte na postulatach teologii protestanckiej, znajdowały swoje odzwierciedlenie nie tylko w etyce czy teorii rządzenia, ale w praktyce - organizacji władz i strukturze miasta. Owa struktura, dzięki wszechstronnej wiedzy i mądrej polityce Henryka Strobanda, była dobrze zorganizowana, praworządna, poparta prokalwińskim kodeksem etycznym, gdzie sprawny aparat władzy surowo egzekwował prawo, wynikające z wiary, która propagowała sumienność i pracowitość oraz dyscyplinowała zachowania społeczne ${ }^{46}$.

Liczne odniesienia i analogie toruńskich dzieł do realizacji artystycznych, powstałych na przełomie XVI i XVII wieku w Gdańsku, były wynikiem ożywionych kontaktów między tymi miastami, zarówno handlowych, gospodarczych, społecznych, jak i kulturalnych. Podłożem szczególnym były jednak związki religijne obu miast; zarówno w Toruniu, jak i Gdańsku członkami rady miejskiej oraz profesorami gimnazjum byli w większości zwolennicy kalwinizmu ${ }^{47}$. Sympatie prokalwińskie były odzwierciedleniem tendencji występującej wówczas w całej Rzeczypospolitej i były charakterystyczne zarówno dla mieszczan, jak i dla szlachty ${ }^{48}$. Podobnie jak w Gdańsku u schyłku XVI wieku, tak i w Toruniu kalwinizm wyznawały najznamienitsze rody - w tym Strobandowie ${ }^{49}$. Mimo zainteresowania postacią samego Henryka Strobanda, rozwojem protestantyzmu w nowożytnym Toruniu, mimo licznych ostatnio opracowań, dotyczących fundacji burmistrza, ten artystyczno-ideowy fenomen nie doczekał się dotychczas całościowego, syntetycznego opracowania.

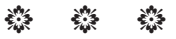

\section{Some facts from mayor Henryk Stroband's politics as to his foundation decorations. A supplement to the iconosphere of modern Toruń}

The article is about one of the great man in history of Torun - Henryk Stroband, a politician who ruled Torun as mayor between 1587 and 1608, which is known as The Gold Age of Torun history. He also got comprehensive education on the well - known European universities.

Henryk Stroband was a founder of famous Academic Gymnasium, too( today it is the first secondary school named after Nicolaus Copernicus). There were always many intellectual elites

45 Susan TIPTON, Res Publica bene ordinata. Regentenspiegel und Bilder vom guten Reginent. Rathausdekorationen in Frühen Neuzeit, Hildesheim 1996, s. 38.

46 KALECIŃSKI 2011, s. 132.

47 Wzrost liczby ewangelików reformowanych w Gdańsku analizuje Katarzyna CIEŚLAK, Między Rzymem, Wittenberga a Genewa. Sztuka Gdańska jako miasta podzielonego wyznaniowo, Wrocław 2000, s. 142-143.

48 Kazimierz MALISZEWSKI, Stosunki religijne $w$ Toruniu $w$ latach 1548-1660, [w:] Historia Torunia, t. 2, cz. 2, W czasach renesansu, reformacji i wczesnego baroku (1548-1660), red. M. Biskup, Toruń 1994, s. 257-300, zwł. 257.

49 TAMŻE, s. 265. 
among the teachers of gymnasium and most of them also entered into The City Council of Torun. Majority of them, which is particularly important, were determined adherents of Calvinist ideology.

The mentioned above Academic Gymnasium, which was initiated on Jan Sturm's idea and university in Strasbourg - upon the rules of Henryk Stroband, it's initiator - was developed and reformed. The mayor's great ambition was to raise this school in Torun to the range of Protestant Academy, for the whole Republic of Poland in the $16^{\text {th }}$ century.

Next, to get better results it was necessary to establish a library, which was arranged in the buildings of old Franciscan monastery. The library was given the rich collection of books and interesting modern ideas for decorations of its buildings - outside and inside. Moreover, the buildings were ornamented and painted with allegorical presentations and the portraits, not only of ancient philosophers, but also with the present scientists, were placed on the walls. The library was also divided into different sections by the walls.

The conception of these presentations and their heroes - I want to add it - related to the curriculum of Academic Gymnasium, which joined Protestant theology and human disciplines: philosophy, grammar, rhetoric with such new subjects like the law, political theory and history. The main aim at young citizens' education was to prepare them for the leading negotiations and making rhetorical speeches which were based on Greek and Roman philosophical heritage.

The following important work initiated by mayor Stroband is supposed to be the extension of town hall as a place for the City Council meeting. In the rooms of its building, rebuilt in the Dutch mannerism style and spirit, the new fireplaces and their mantelpieces and the portals appeared with inscriptions glorifying good rules and particularly political propaganda or current reforms.

Especially, the rich pictorial decor with the impressive wood carved frame was made to the ceiling of Council Room. There, Henryk Stroband as an author of the project, situated the scenes which were specific "praecepta politica" for those authorities in Torun. The pictures were full of allegorical content, relating to religious and social themes.

However, the particular place was given there to contemporary themes like security or care of the poorest citizens of Torun.

Henryk Stroband also watched so - called organ prospect and their decorations with a wealth of ornament, in post - Franciscan church where was the center of Protestant's religious life in Toruń.

Concluding, in his foundation we can find a lot of examples as to virtue personifications or the ideas of mythological deities from history and an ancient literature. These all facts became the essential source of such excellent administration and the political, religious and social situation in Torun in those times of its mayor - Henryk Stroband. 


\section{SPIS ILUSTRACJI:}

1. Toruń, budynek Arsenału, przebudowany w 1597, wg ALBUM STEINERA, ryc. 77, s. 125.

2. Toruń, budynek głównego odwachu, wg ALBUM STEINERA, ryc. 67, s. 115.

3. Toruń, budynek „Ekonomii” Toruńskiego Gimnazjum Akademickiego, wzniesiony w latach 15981601, wg ALBUM STEINERA, ryc. 82, s. 130.

4. Toruń, Ratusz Staromiejski, przebudowany w latach 1602-1605. Stan sprzed pożaru w 1703 roku, wg ALBUM STEINERA, ryc. 16, s. 62.

5. Peter Ringering (?), projekty figur: A, B, C, D Prudentia, Pietas, Iustitia, Concordia-sangwina, Muzeum Narodowe w Gdańsku, wg Marcin KALECIŃSKI, Mity Gdańska. Antyk w publicznej sztuce protestanckiej res publiki, Gdańsk 2011, il. 134, A-D.

6. Toruń, kościół NMP, organy, fot. A. Skowroński.

7. Toruń, kościół NMP, ambona, fot. J. Raczkowski.

8. Toruń, kościół NMP, organy - fragm., fot. A. Skowroński.

9. Toruń, kościół NMP, organy - fragm., fot. A. Skowroński.

10. Toruń, kościół św. Jakuba, organy, fot. A. Skowroński. 


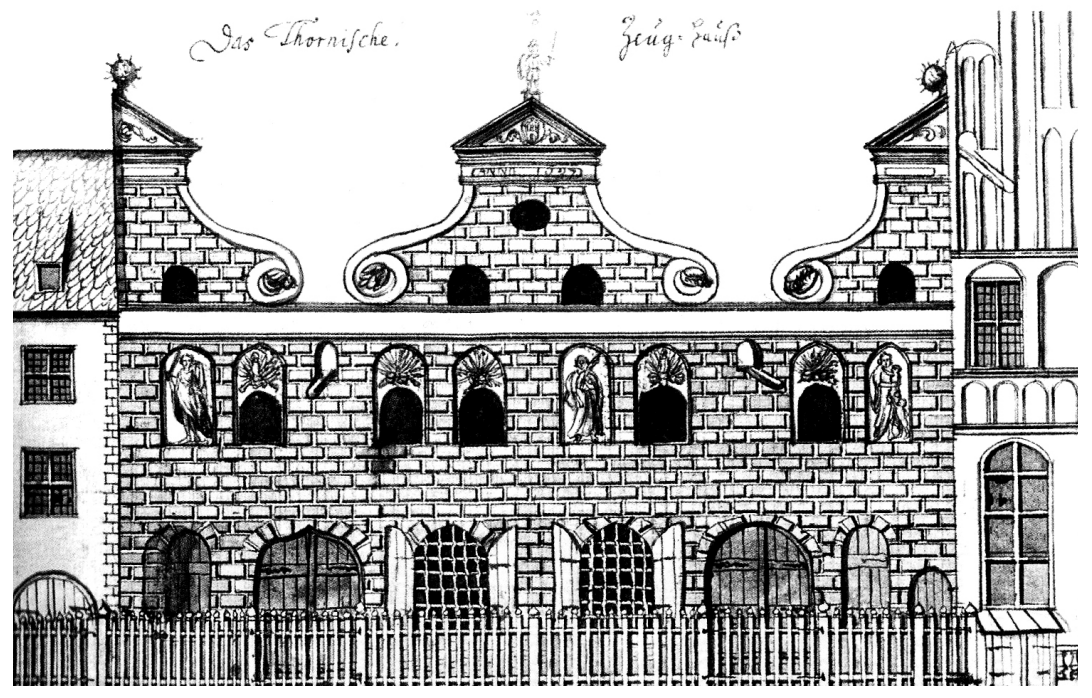

Il. 1 Toruń, budynek Arsenału, przebudowany w 1597, wg ALBUM STEINERA, ryc. 77, s. 125

$$
\text { Tie Thornifine, Savitu Staise. }
$$

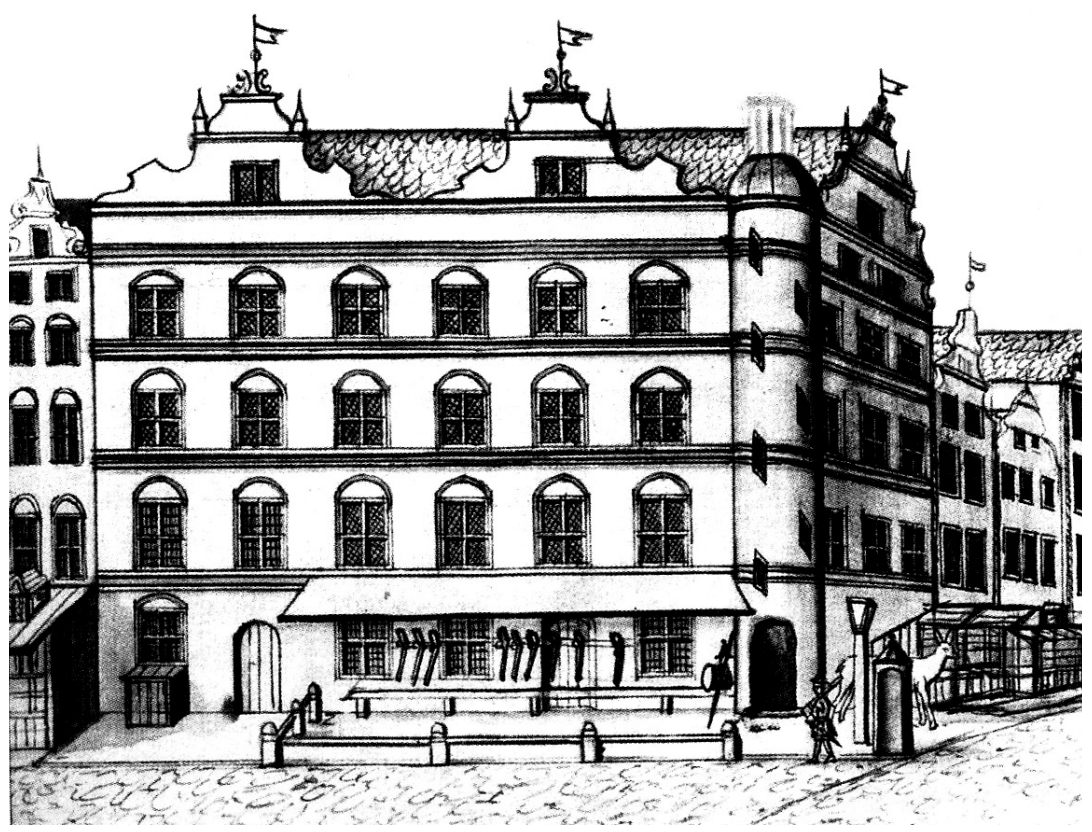

Il. 2 Toruń, budynek głównego odwachu, wg ALBUM STEINERA, ryc. 67, s. 115 


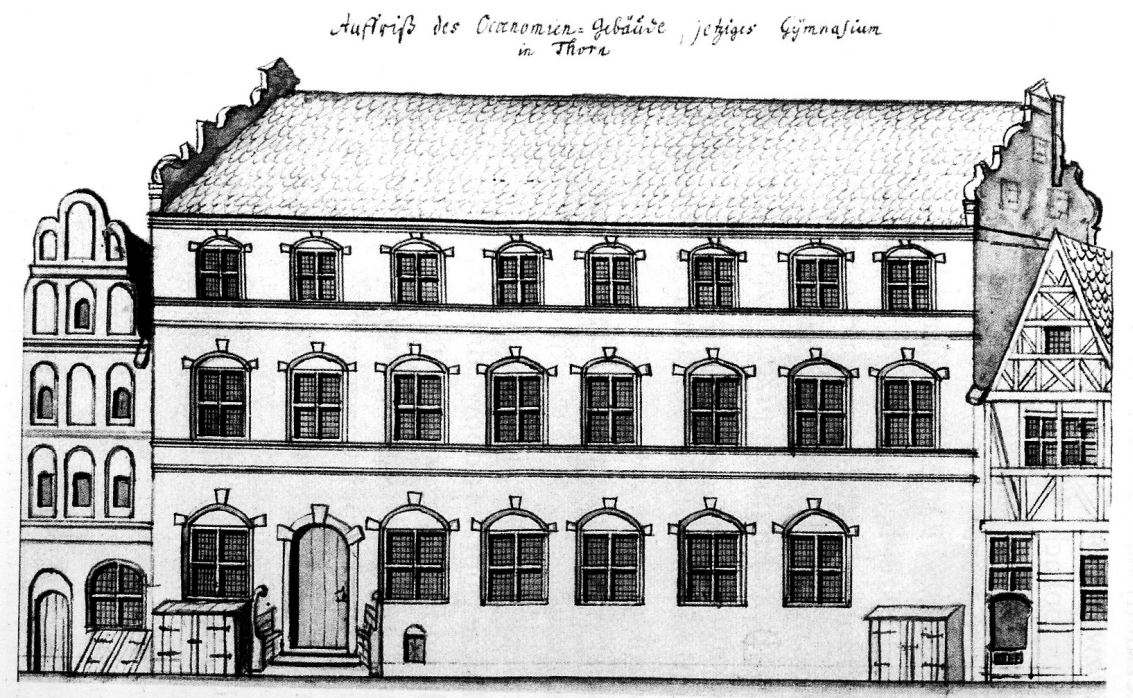

Il. 3 Toruń, budynek „Ekonomii” Toruńskiego Gimnazjum Akademickiego, wzniesiony w latach 1598-1601, wg ALBUM STEINERA, ryc. 82, s. 130

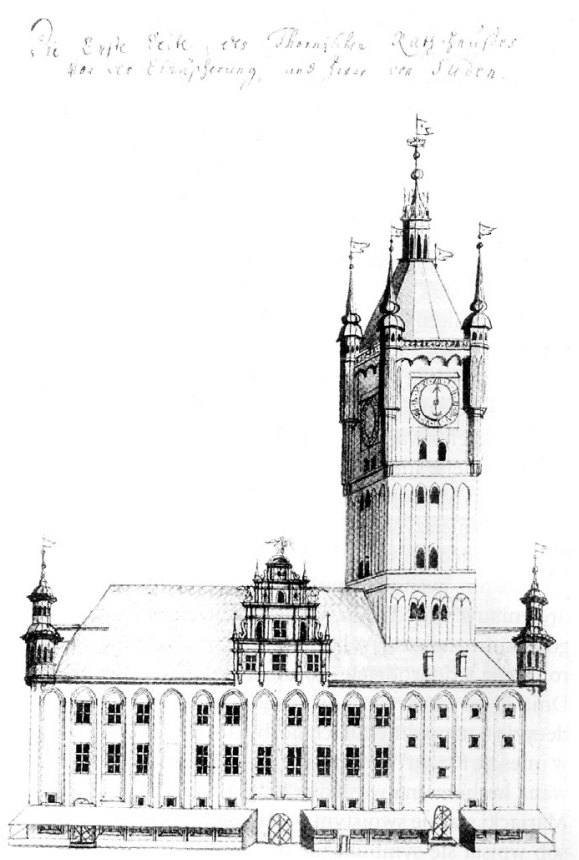

Il. 4 Toruń, Ratusz Staromiejski, przebudowany w latach 1602-1605. Stan sprzed pożaru w 1703 roku, wg ALBUM STEINERA, ryc. 16, s. 62 

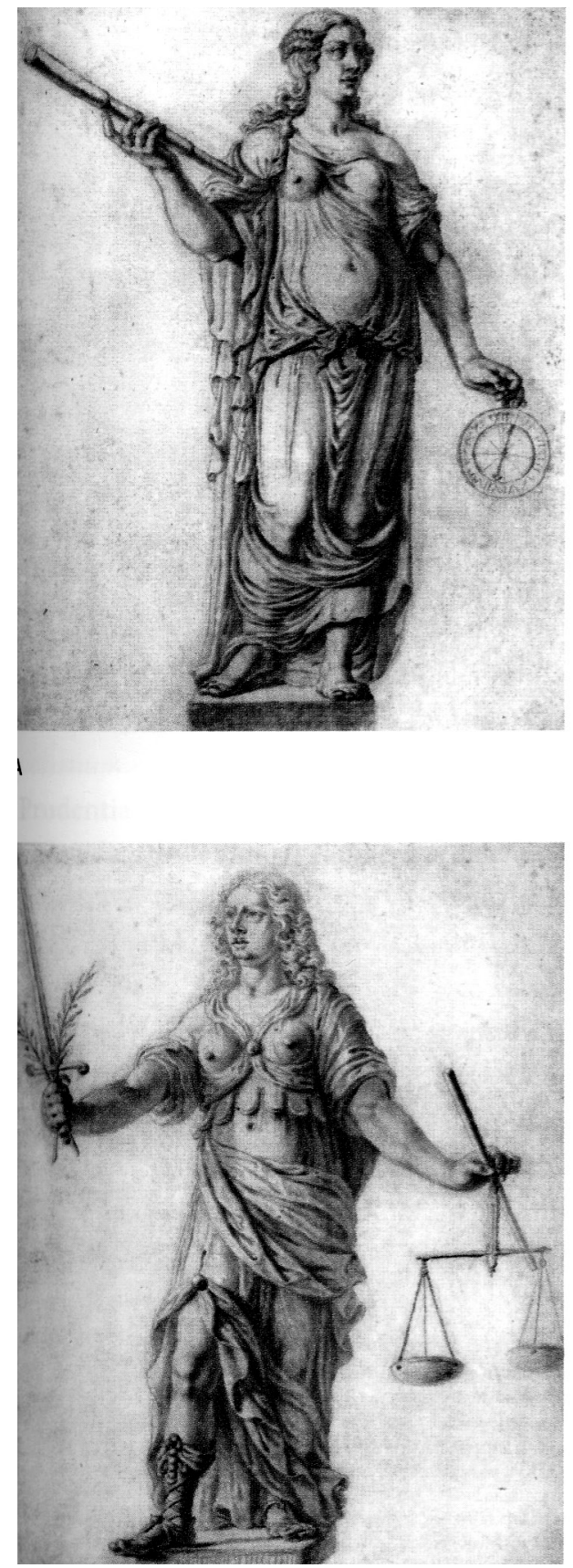

Il. 5 Peter Ringering (?), projekty figur: A, B, C, D Prudentia, Pietas, Iustitia, Concordia-sangwina, Muzeum Narodowe w Gdańsku, wg Marcin KALECIŃSKI, Mity Gdańska. Antyk w publicznej sztuce protestanckiej res publiki, Gdańsk 2011, il. 134, A-D

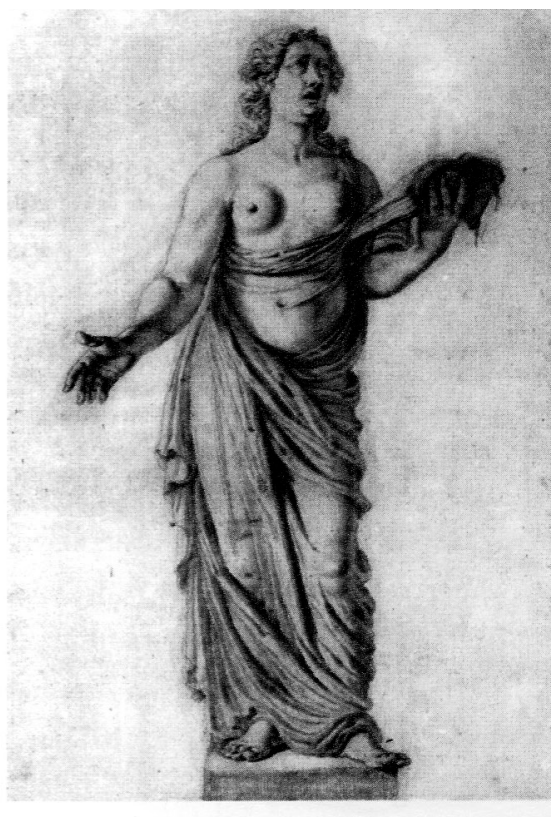

B

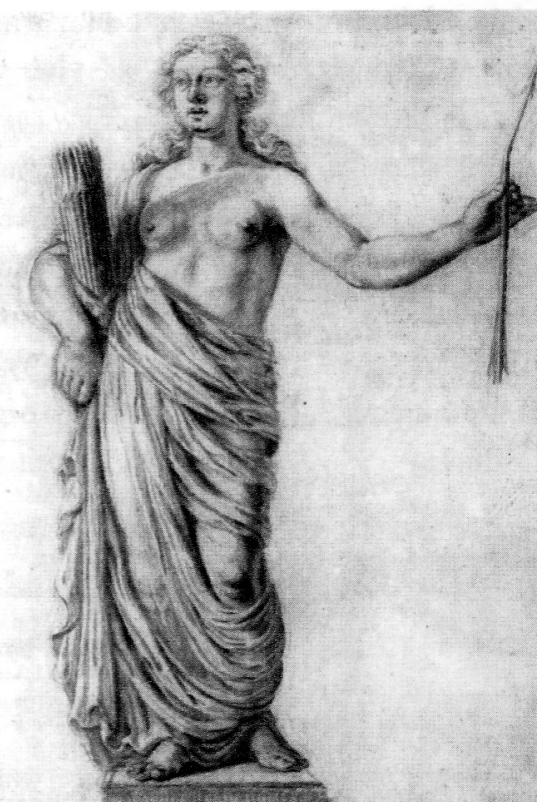




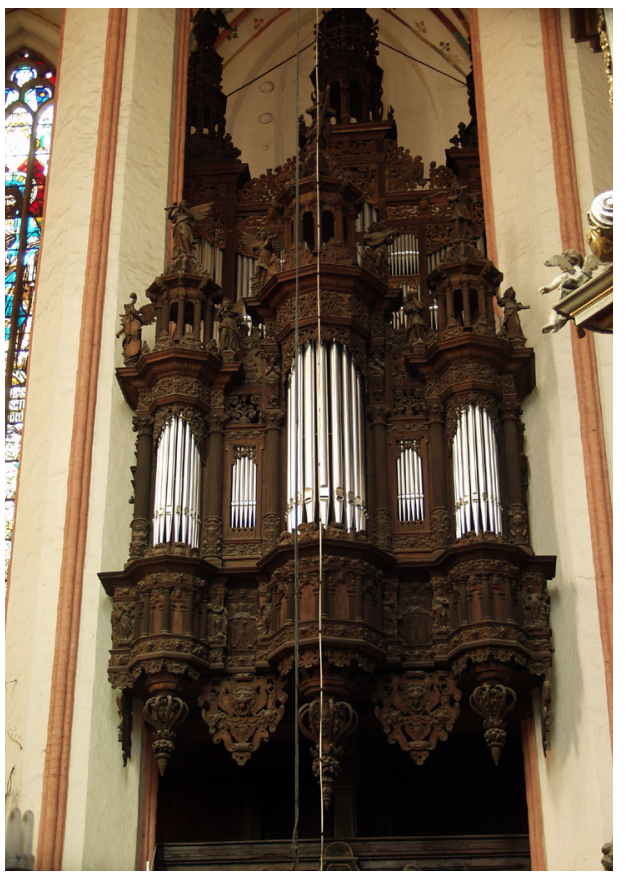

Il. 6 Toruń, kościół NMP, organy, fot. A. Skowroński

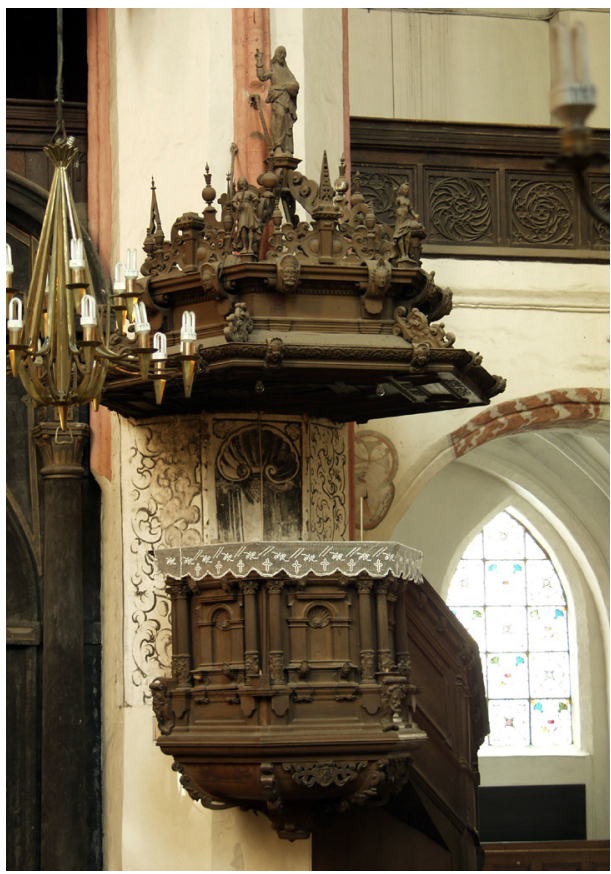

Il. 7 Toruń, kościół NMP, ambona, fot. J. Raczkowski

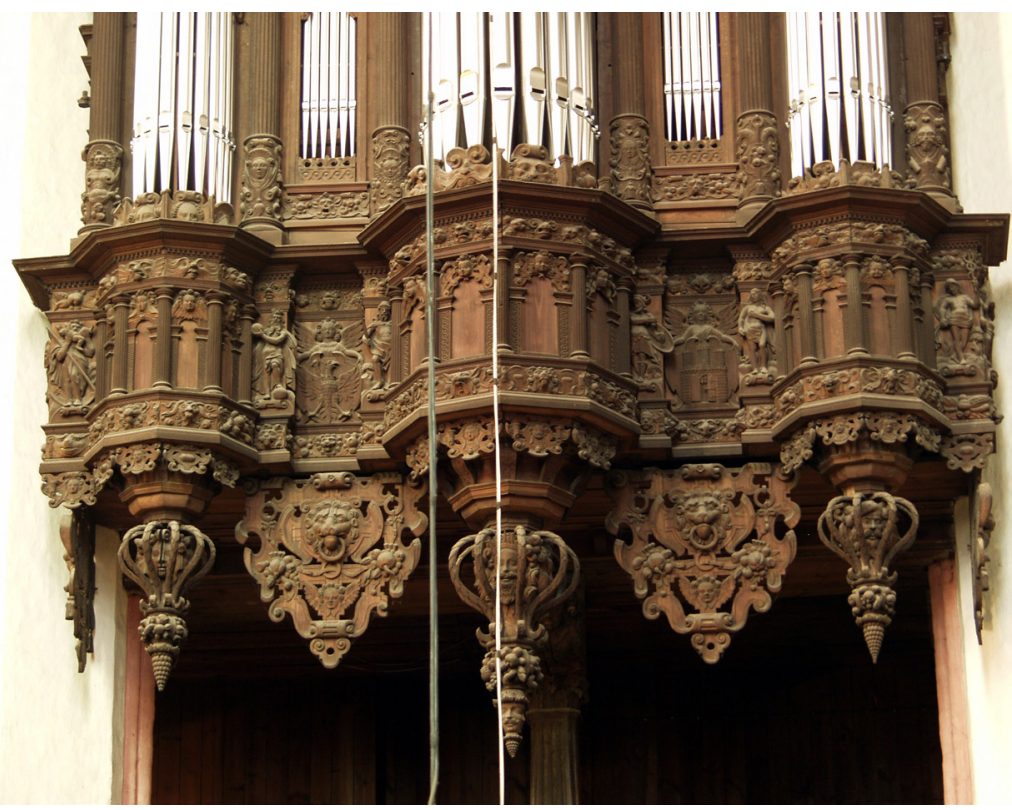

Il. 8 Toruń, kościół NMP, organy - fragm.., fot. A. Skowroński 
Małgorzata Wawrzak

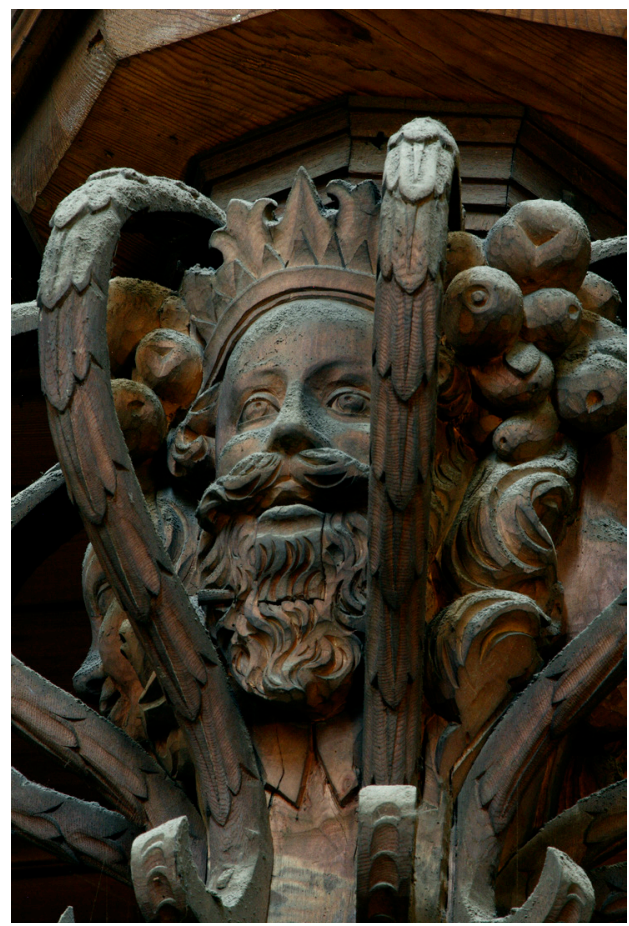

Il. 9 Toruń, kościół NMP, organy - fragm., fot. A. Skowroński
Treści polityczne zawarte $w$ dekoracjach...

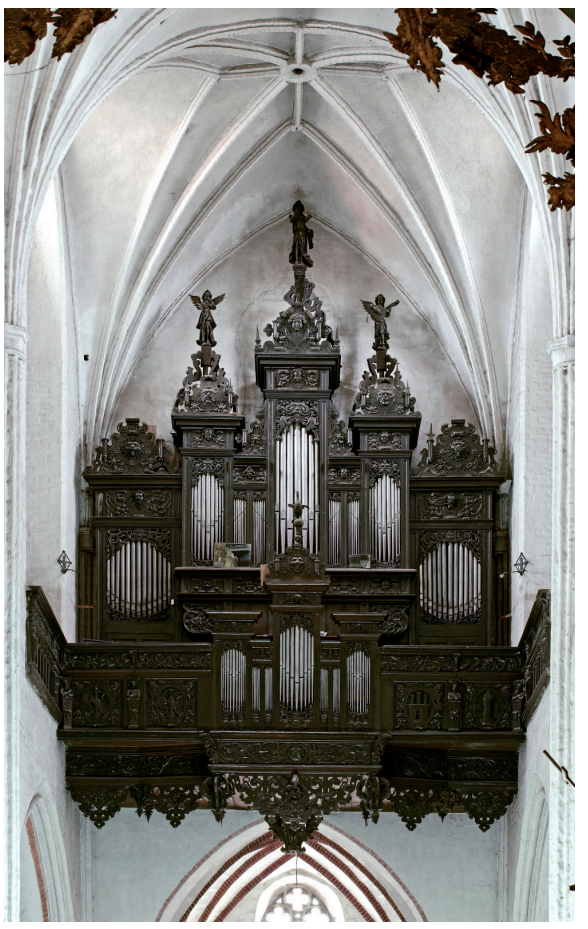

Il. 10 Toruń, kościół św. Jakuba, organy, fot. A. Skowroński 